\title{
Üniversite Öğrencilerinin Benlik Saygılarının Stresle Başaçıkma Tutumlarını Yordama Gücü ${ }^{1}$
}

\author{
Selahattin AVŞAROĞLU² ve Asem IDAYEVA ${ }^{3}$
}

\section{$\ddot{O} z$}

$\mathrm{Bu}$ araştırmanın amacı, üniversite öğrencilerinin benlik saygılarının stresle başaçıkma tutumlarını yordama gücünü incelemektir. Araşıırma grubunu, 2017-2018 eğitim-öğretim yllında Kırgızistan-Türkiye Manas Üniversitesi ve Oş Devlet Üniversitesi’nin farklı fakültelerinde öğrenim görmekte olan öğrenciler oluşturmuştur. Araştırma, tesadüfi eleman örnekleme yöntemi ile seçilen toplam 303 öğrenciden oluşmuştur. Verilerin toplanmasında, Arıcak (1999) tarafindan geliştirilmiş olan 'Benlik Saygısı Ölçeği’ ve Özbay (1997) tarafindan geliştirilmiş olan 'Stresle Başaçıkma Tutumları Envanteri' kullanılmıştır. Araştırma, genel tarama modelinin bir alt türü olan ilişkisel tarama modeline uygun olarak gerçekleştirilmiştir. Verilerin analizinde korelâsyon ve regresyon analizi tekniği kullanılmıştır. Araştırma bulgularına göre benlik saygısının stresle başa çıkmada bilişsel yeniden yapılandırma, aktif planlama ve dine sığınma ile pozitif yönlü anlamlı bir ilişkiye sahip olduğu görülmüştür. Buna karşıllk, stresle başaçıkmanın kaçma biyo-kimyasal, kaçınma duygusal eylemsel ve dış yardım arama alt boyutları, benlik saygisı ile negatif yönlü anlamlı bir ilişkiye sahip olduğu saptanmıştır. Benlik saygisı toplam alt boyutlarının (benlik değeri, öz-güven, depresif duygulanım, kendine yetme, başarma ve üretkenlik) stresle başaçıkma tutumlarını güçlü bir şekilde yordadığı bulunmuştur.

Anabtar Kelimeler: Benlik, Benlik Saygisı, Stres, Stresle Başaçıkma, Stres Yönetimi

\section{Analysis of Self Esteem and Coping Levels of Stress of University Students}

\begin{abstract}
The study is aimed at regression analysis of self-esteem and coping with stress attitudes of university students. The study group consists of students, who studied in different faculties of Kyrgyz-Turkish Manas University and Osh State University in 2017-2018 academic years. 303 students were selected by random sampling method. "Self-esteem scale", developed by Arıcak (1999) and "Attitude of coping with stress inventory", developed by Ozbay (1997) were used for data collection. The research was conducted in accordance with the relational screening model, a sub-type of the general survey model. Correlation and regression analysis were used for data analysis. In the study, self-esteem was found to be positively correlated with such stress-coping dimensions like acceptance-cognitive restructuring, active planning and religious asylum, while negative correlation was found between self-esteem and stress-coping dimensions like avoidance-isolation (biochemical), avoidance-isolation (emotional-actual) and seeking external aid. It was found that coping with stress attitudes are strongly predicted by self-esteem sub-dimensions (self-value, selfconfidence, depressive affect, self-sufficiency and achievement and productivity).
\end{abstract}

Key Words: Self, Self Esteem, Stress, Coping with Stress, Stress Management

\section{Atıf İçin / Please Cite As:}

Avşaroğlu, S. ve İdayeva, A. (2020). Üniversite öğrencilerinin benlik saygılarının stresle başaçıkma tutumlarını yordama gücü. Manas Sosyal Araștırmalar Dergisi, 9(1), 411-422.

\footnotetext{
1 Bu makale “Üniversite Öğrencilerinin Benlik Saygısı ve Stresle Başaçıkma Tutumlarının İncelenmesi” başlıklı doktora tez çalışmasına dayalı olarak hazırlanmıştır.

2 Prof. Dr. - Necmettin Erbakan Üniversitesi, Ahmet Keleşoğlu Eğitim Fakültesi, seloavsar@gmail.com ORCID: 0000-0002-0953-2922

${ }^{3}$ Dr. - Kırgızistan-Türkiye Manas Üniversitesi, Edebiyat Fakültesi, Eğitim bilimleri Bölümü, idaeva.asem88@gmail.com ORCID: 0000-0002-6134-9244
} 


\section{Giriş}

İnsanoğlunun yaşamında kendine ait özelliklerin farkında olma çabası her geçen gün daha da önemli hale gelmektedir. Dünyanın çok hızlı değişimi ve gelişsimine ayak uydurabilmek için bu çabanın eğitimsel süreçlerinin olması ve temel beceriler geliştirilmesinin önemi artmaktadır. Bu süreçte bireyin kendini tanımasına ve farkında olarak tepkiler vermesine imkânlar sağlanabilir. Bu süreçte bireyin benlik yapıları, benlik kavramı ve benlik saygısı, onun yaşam olaylarını algılama biçimini ve etkileşimini etkilemektedir (Avşaroğlu, 2007, s. 26). Benlik kavramı ile benlik saygısı çoğunlukla birbiri yerine kullanılmakta olmasına karşın aslında birbirlerinden farklı anlamlar taşımaktadırlar. İkisi de bireyin kendi benliği hakkındaki fikirleri kapsamakla birlikte benlik saygısı, benlik kavramından daha farklı değerlendirici olguları içine almaktadır (Madenoğlu, 2010, s. 59).

Benlik en geniş manada bireyin kendisinin ne olduğunu söyleyebileceği her şeyin toplamı olarak tanımlanabilir (Kağıtçıbaşı, 2012, s. 112). Benlik kişinin kendisine ilişkin ve kendisi tarafindan oluşturulan zihinsel bir fotoğraftır (Caspi, Roberts ve Shiner, 2005, s. 543-584). Çocukluktan itibaren çevreyle kurulan ilişkiler, etkileşimler ve edinilen deneyimlerle şekillenip gelişen, öznel ve nesnel nitelikli ögelerden oluşan benlik, bireyin birey olmasını sağlayan, diğerlerinden farklı kılan duygu, tutum ve davranışların tamamının örgütlenmiş bütünlügüuür (McCrae ve Costa, 2008, s. 159-181).

Benlik saygısı, kişinin kendini değerlendirmesi sonunda ulaştığı benlik kavramını onaylamasından doğan beğeni durumudur. Kişi kendini eleştirebilir ya da kendini tümden olumlu bulabilir. Kişinin kendini beğenmesi, kendi benliğine sayg1 duyması için üstün niteliklerinin olması gerekmez, çünkü benlik sayg1sı, kendini olduğundan aşağı ya da olduğundan üstün görmeksizin kendinden memnun olma, kendini olumlu, beğenilmeye, sevilmeye değer bulma ve özüne güvenmeyi sağlayan olumlu bir ruh halidir (Yörükoğlu, 1993, s.93).

Benlik saygısı yüksek olan kişide kendine güven, iyimserlik, başarma isteği gibi olumlu ruhsal nitelikler bulunur. Yüksekbenlik saygısına sahip bireylerin kendine güvenen, olumsuz ve zayıf yönlerinin farkında olma ve eksikliklerini gidermeye çalı̧̧ma, değişime açık olma, üretkenlik, olumsuzluklarla baş edebilme ve stresi tolare edebilme gibi özelliklere sahip oldukları saptanmıştır (Robins, Tracy, Trzesniewski, Potter ve Gosling, 2001, s.463-482). Yüksek benlik saygısına sahip birey sosyal çevresi tarafindan sevildiğini, güvenilir bir kişi olduğunu düşünür; kendini sever, yeteneklerinin farkındadır ve mevcut yetenek ve becerilerini geliştirmeye odaklanır. Bu açıdan bu bireyler psikopatolojik olarak daha düşük riske sahiptirler (Waldron, Scarpa ve Kim-Spoon, 2018, s.277-284). Buna karşllık benlik saygisı düşükbir kimsenin kendine güveni azdır, kolay umutsuzluğa kapılır, kısacası olumsuz ruhsal belirtiler geliştirmeye daha yatkındır (Yörükoğlu, 1993, s. 103). Düşük benlik saygısına sahip bireylerde ise, görev almaktan ve yeni şeyler denemekten kaçınma, övgü ve eleştirileri kabullenmede güçlükler, otoriter olma eğilimi, öz güven eksikliği, bağımlı kişilik yapısına sahip olma ve düşük yaratıcıllk gözlenir. Düşük benlik saygısı olan bireyler, öfke kontrolünü sağlamakta zorlanır (Palermiti, Servidio, Bartolo ve Costabile, 2017, s.136-141). Sabırsız, beklemekten hoşlanmayan bir yapıya sahiptir ve başarısızlık karşısında kendini değersiz hissetme eğilimindedirler. Düşük benlik saygısına sahip birey gelecek hakkında olumsuz düşüncelere sahiptir (Robinsvd., 2001, s. 463-482). Yapılan pek çok araştırmada düşük benlik saygisı bulunan bireylerde intihar davranışları, yeme bozuklukları, depresyon, anksiyete gibi duygusal ve davranışsal sorunların daha fazla görüldüğü saptanmıştır (Orth, Robins, Meier ve Conger, 2016, s. 133-149).

Benlik saygısı ile ilgili olduğu düşünülen diğer bir kavram stresle başa çıkmadır. Bireyin, fizik ve sosyal çevreden gelen uyumsuz koşullar nedeniyle, bedensel ve psikolojik sınırlarının ötesinde harcadığı gayrete "stres" adı verilir (Cüceloğlu, 1994, s.321). Stres araştırmalarının babası olarak bilinen HansSelye stresi vücudun karakteristik özelliği olmayan tepkisi olarak tanımlamıştır (Aydın ve Çavuş, 2017, s.81). Stres organizmanın fizik ve ruhsal sınırlarının zorlanması ve tehdit edilmesi ile ortaya çıkan bir durumdur (Baltaş ve Batlaş, 2000, s.40). Araştırmalar, stres kaynaklarından çok, strese maruz kalan kişinin tehdit algisının strese yol açtı̆̆ın göstermektedir. Bu algı nedeniyle stresi herkes farklı sebeplerden dolayı farklı düzeylerde yaşar. Bir kişi için stres verici olay, diğeri için stres kaynağı olarak algılanmayabilir. Hatta diğerinin stres kaynağ1 olarak görmemesini bilmek, o kişi için ayrı bir stres kaynağı olabilir (Baltaş, 2010, s.56).

Stresin çeşitli belirtileri vardır.Bu belirtiler;fiziksel, duygusal, zihinsel ve sosyal olmak üzere dört grupta toplanabilir (Braham, 1998, s. 52-54). Fiziksel belirtiler; baş ağrısı, düzensiz uyku, sırt ağrıları, çene kasılması veya diş gıcırdatma, kabızlık, ishal ve kolit, döküntü, kas ağrıları, hazımsızlık ve ülser, yuksek tansiyon veya kalp krizi, aşırı terleme, iştahta değişiklik, yorgunluk veya enerji kayıplarıdır. Duygusal belirtiler; kaygı veya endişe, depresyon veya çabuk ağlama, ruhsal durumun hızlı ve sürekli değişmesi, 
asabilik, gerginlik, özgüven azalması veya güvensizlik hissi, aşırı hassasiyet veya kolay kırılabilirlik, öfke patlamaları, saldırganlık veya düşmanlık duygusal olarak tükendiğini hissetme gibi belirtilerdir. Zihinsel belirtiler; yoğunlaşma, karar vermede güçlük, unutkanlık, zihin karışıklı̆ı, hafızada zayıflık, aşırı derecede hayal kurma, tek bir fikir veya düşünceyle meşgul olma, mizah anlayışı kaybı, düşük verimlilik, iş kalitesinde düşüş, hatalarda artış, muhakemede zayıflama gibi belirtiler. Sosyal belirtiler ise insanlara karşı güvensizlik, başkalarını suçlamak, randevulara gitmemek veya çok kısa zaman kala iptal etmek, insanlarda hata bulmaya çalışmak ve sözle rencide etmek, haddinden fazla savunmacı tutum, birçok kişiye birden küs olmak gibi belirtiler de sosyal belirtiler olarak sayılabilir. Strese karşı verilen tepkiler uzun bir zaman dilimi içinde kronik hastalıkların gelişmesine zemin hazırlar. Streslerin sıklığı ve yoğunluğu zamanı kısaltabilir. Bu hastalıklar; başağrısı, yüksek tansiyon, kalp rahatsızlıkları gibi bedensel hastalıklar olabildikleri gibi, psikolojik veya zihinsel hastalıklar da olabilir (Baltaş ve Baltaş, 2000, s.58-59).

Stresle başaçıkmak ve yaşam kalitesini artırmak amacıyla, durumu ya da duruma verilen tepkileri değiştirmeye stres yönetimi denir (Güçlü, 2001, s.101). Stresle başaçıkma dışsal ve içsel tepkileri ya da bunlar arasındaki çatışmaları denetim altına alamaya odaklı, bireyin kaynaklarını genişletici veya sınırlayıcı davranışsal ve zihinsel gayretler olarak tanımlanmaktadır (Savcı ve Aysan, 2014, s.45). Başaçıkma stratejilerini, probleme odaklı ve duygu odaklı başaçıkma stratejileri (Folkman ve Lazarus, 1988, s.468; Ptacek vd., 1992, s.750; LeSergent ve Haney, 2005, s.320) olarak sinfflandırmak mümkündür. Problem odaklı yaklaşım, stresin kaynakları üzerinde odaklanmayı salık veren ve diğerine göre daha etkin bir yaklaşım olarak kabul görmektedir. Bu yaklaşımı izleyenlerin daha iyimser ve stresle başaçıkmada daha başarılı oldukları görülmektedir. Duygu odaklı yaklaşım ise genellikle, stresin kaynaklarından daha çok, olayın iyi yönleri üzerinde odaklanmayı ve "daha kötüsü de olabilirdi!", "her işte bir hayır vardır!" gibi düşüncelerle stresle başetmeyi salık veren bir yaklaşım olarak değerlendirilmektedir (Aydın, 2016, s. 134). $\mathrm{Bu}$ yaklaşımı izleyenlerin stres kaynağını pasif bir şekilde kabul ettikleri ve dolayısıyla da, stresle başaçıımada daha az başarılı oldukları görülmektedir (Soysal, 2009, s.32). Stres durumlarına karşı bireyin güçlü bir şekilde onunla başetmesi önemli bir olaydır. Bunun için bireyin sosyal becerisi ve benlik yapısının güçlü olması gerektiği görüşü hâkimdir. Güçlü bir benlik, yüksek bir özgüven, sağliklı bir başarma ve üretkenlik duygusu birçok stres faktörünü çözmeye yeten ve üstesinden gelen düzeylerdir. Bunun için benlikle stres ilişkisi ya da stresle başaçıkma durumlarının bilinmesinde sayısız yarar vardır.

Bu çalışmanın temel amacı, benlik saygısı ile stresle başaçıkma arasında bir ilişki var mıdır? sorusuna yanıt aramaktır. Diğer bir amacı da üniversite öğrencilerinin benlik saygısı düzeylerinin stresle başaçıkma tutumlarını yordama gücünü belirlemektir. Araştırmada bu temel amaç çerçevesinde aşağıdaki sorulara yanıt aranmıştır:

1. Üniversite öğrencilerinin benlik saygısı ölçeği alt boyutları (benlik değeri, özgüven, depresif duygulanım, kendine yetme, başarma ve üretkenlik) iledine sığınma (dine yönelme) arasında anlamlı bir ilişki ve yordama gücü var mıdır?

2. Üniversite öğrencilerinin benlik saygısı alt boyutları ile dış yardım arama arasında anlamlı bir ilişki ve yordama gücü var mıdır?

3. Üniversite öğrencilerinin benlik saygısı alt boyutları ile aktif planlama arasında anlamlı bir ilişki ve yordama gücü var midır?

4. Üniversite öğrencilerinin benlik saygısı alt boyutlarilekaçma-soyutlama (duygusal eylemsel) arasında anlamlı bir ilişki ve yordama gücü var mıdır?

5. Üniversite öğrencilerinin benlik saygısı alt boyutları ile kaçma-soyutlanma (biyokimyasal) arasında anlamlı bir ilisski ve yordama gücü var mıdır?

6. Üniversite öğrencilerinin benlik sayg1sı alt boyutları ile kabul-bilişsel yeniden yapılandırma arasında anlamlı bir ilişki ve yordama gücü var mıdır?

\section{Yöntem}

$\mathrm{Bu}$ araştırmada genel tarama modelinin bir alt türü olan ilişkisel tarama modeli kullanılmıştır. İlişkisel tarama modelleri, iki ve daha çok sayıdaki değişken arasında birlikte değişim varllğını ve/veya derecesini belirlemeyi amaçlayan araştırma modelleridir (Karasar, 2008, s.79). 


\section{Çalışma Grubu}

Araştırmanın evrenini, 2017-2018 eğitim-öğretim yılında Kırgızistan Türkiye Manas Üniversitesi ve Oş Devlet Üniversitesinde öğrenim görmekte olan öğrenciler oluşturmaktadır. Araştırma örneklemi, Kırgızistan Türkiye Manas Üniversitesi ve Oş Devlet Üniversitesi'nin Edebiyat Fakültesi, Fen Fakültesi, İletişim Fakültesi, İlahiyat fakültesinde ve bir, iki, üç ve dördüncü sınıflarında eğitim görmekte olan öğrencilerden oluşmaktadır. Araştırma grubu tesadüfí eleman örnekleme yöntemle seçilmiş toplam 303 öğrenciden oluşmaktadır.

\section{Veri Toplama Araçları}

Benlik Saygısı Ölçeğ̈.Arıcak (1999) tarafindan geliştirilmiş olan 'Benlik Saygisı Ölçeği’ 5’li likert tipi derecelendirmeyle düzenlenmiștir. Ölçek maddeleri, "5-Tamamen Kat1liyorum,4-Katıllyorum, 3Kararsızım, 2-Katılmıyorum, 1-Kesinlikle Katılmıyorum" olarak puanlanmaktadır. Ölçekteki ifadelerin 13'ü olumlu, 19'u ise olumsuz olmak üzere toplam 32 maddeden oluşmaktadır. Ölçek, beş faktöre ayrılmıştır ve kuramsal olarak benlik saygısının; benlik değeri, kendine güven, depresif duygulanım, kendine yetme, başarma ve üretkenlik duygusu şeklinde boyutları olduğu için ölçekte bu boyutlar oluşturulmuştur. Benlik değeri alt boyutu; bireyin kendinde olan ve olması gereken özelliklere verdiği değerin düzeyini; özgüven alt boyutu; bireyin kendi özelliklerine bir değer atfetme ve bu değerler sayesinde kendini onaylama düzeyini; depresif duygulanım alt boyutu; bireyin çaresizlik, zayıflık ve güçsüzlük bakımından algılama düzeyini; kendine yetme alt boyutu; bireyin zihinsel ve davranışsal anlamda kendi beklentilerini ve hedeflerini gerçekleştirme düzeyini ve başarma ve üretkenlik alt boyutu ise bireyin kendini yeterince başarılı ve faydalı görme düzeyini ölçmektedir.

Ölçeğin Cronbach Alfa iç tutarlık katsayısı .90 olarak bulunmuştur. Korelasyon katsayıları alt ölçeklere göre, Benlik değeri; .74, Özgüven; .68, Depresif duygulanım; .75, Kendine yetme; .60, Başarma ve üretkenlik; 70 şeklinde hesaplanmıştır (Arıcak, 1999). Ölçek 32 ile 160 arasında toplam puan vermektedir. Alınan ortalama puanın yüksekliği, benlik saygısı düzeyinin yüksek olduğu anlamını taşımaktadır.

Stresle Basaçkma Tutumlar Envanteri (SBTE). Ölçek, Özbay (1993) tarafindan ABD'de üniversitede öğrenim gören yabanc1 uyruklu öğrencilere yönelik geliştirilmiş daha sonra, Özbay ve Şahin (1997) tarafından Türkçe'ye uyarlanmıştır. Envanter farklı stres durumlarında bireylerin nasıl baş ettiğini ölçmeye yönelik olarak hazırlanmışır. 56 maddeden oluşan özgün form Türkçe'ye uyarlanması sonucunda 43 maddeye düşmüş ve ifadelerin tümü pozitif yönlü olup, ters ifade yer almamaktadır. Maddeler 5'li likert şeklinde düzenlenmiş ve "hiçbir zaman, ara sıra, bazen, sık sık, her zaman" seçeneklerini içermektedir.

Ölçeğin alt boyutları; aktif planlama, dış yardım arama, dine sığınma (dine yönelme) kaçma-soyutlama (duygusal-eylemsel), kaçma soyutlanma (biyokimyasal) ve kabul-bilişsel yeniden yapılanma olarak adlandırılmıştır. Altı boyutlu ölçek toplam varyansın \%50,2'sini açıklamaktadır. Genel güvenilirlik katsayısı .81 olarak hesaplanırken, alt boyutlardan aktif planlama boyutu için .75, dış yardım arama boyutu için .81, dine sığınma boyutu için .89, kaçma soyutlanma-duygusal eylemsel boyutu için .62, kaçma soyutlanma-biyo kimyasal boyutu için .56 ve kabul-bilişsel yeniden yapılandırma boyutu için ise .56 olarak bulunmuştur (Özbay ve Şahin, 1997).

\section{Verilerin Analizi}

Araştırmada veri toplama araçlarından elde edilen veriler SPSS 16.00 paket programı kullanılarak analiz edilmiştir. Değişkenler arasındaki ilişkileri incelemek için korelasyon ve regresyon analizleri yapılmıştır.

\section{Bulgular}

Tablo 1'de benlik saygısı ile stresle başa çıkmada dine sı̆̆ınma arasındaki ilişkinin belirlenmesi amacı ile yapılan regresyon analizi sonuçlarına yer verilmiştir. 
Tablo 1.Benlik Saygısı ile Stresle Başa Çımada Dine Sı̆̆ınma Arasındaki İlişkiye Ait Bulgular

\begin{tabular}{|c|c|c|c|c|c|c|c|c|}
\hline Model & $B$ & Standart Hata & Beta & $t$ & $p$ & $r$ & Partial $r$ & Part $r$ \\
\hline (Sabit) & 3.719 & .359 & & 10.351 & .000 & & & \\
\hline Benlik Değeri & -.057 & .139 & -.035 & .406 & .685 & -.099 & -.024 & -.023 \\
\hline Öz Güven & -.171 & .189 & -.074 & .905 & .366 & -.052 & -.052 & -.052 \\
\hline Depresif Duygulanım & .264 & .119 & .210 & -2.384 & .016 & .126 & .080 & .079 \\
\hline Kendine Yetme & -.053 & .124 & -.030 & .425 & .671 & -.043 & -.025 & -.024 \\
\hline Başarma ve Üretkenlik & -.170 & .139 & -.095 & 1.221 & .223 & -.111 & -.071 & -.070 \\
\hline Bağımlı Değisşken: Dine Sığınma & & $\mathrm{F}=4.382 ; \mathrm{p}<.05$ & & $\mathrm{R}=.151$ & & $\mathrm{R}^{2}=.02$ & & \\
\hline
\end{tabular}

Tablo 1 incelendiğinde, stresle başaçıkma tutumları alt boyutlarından dine sı̆̆ınma ile benlik saygısı alt boyutlarından benlik değeri ( $r=-.099)$, öz güven $(r=-.052)$, kendine yetme $(r=-.043)$ ve başarma üretkenlik $(\mathrm{r}=-.111)$ alt boyutları arasında negatif bir ilişkinin olduğu görülmektedir. Buna karşılık benlik saygısının depresif duygulanım alt boyutu ile stresle başaçıkmada dine sığınma arasında ise pozitif ilişki saptanmıştır $(\mathrm{r}=$.126). Bu durum, benlik değeri, Öz-güven, kendine yetme ve başarma üretkenlik arttıkça dine sığınma tutumu puanlarının düştüğünü, buna karşılık depresif duygulanım puanları yükseldikçe dine sığınma puanlarının da yükseldiğini ortaya koymaktadır.

Benlik saygısının alt boyutları ile stresle başaçıkmada dine sığınma tutumu arasında kurulan model istatistiksel bakımdan anlamlı bulunmuştur $(\mathrm{F}=4.382, \mathrm{p}<.05)$. Bu durum genel olarak benlik saygisının dine sığınma tutumunu anlamlı düzeyde açıkladığını göstermektedir. Benlik saygısı beş alt boyutu birlikte (benlik değeri, öz-güven, depresif duygulanım, kendine yetme, başarma ve üretkenlik) dine sığınma tutumuna ilişkin varyansın\% 2,3'ünü açıklamaktadır ( $\left.\mathrm{R}=.151, \mathrm{R}^{2}=.023\right)$. Bu durum dine sığınma tutumunun \% 2,3’ünün benlik sayg1sı tarafından belirlendiğini göstermektedir.

Standartlaştırılmamış Beta katsayıları incelendiğinde dine sı̆̆ınma tutumuna ait her bir puan üzerinde benlik değeri (-0.057), öz-güven (-0.171), depresif duygulanım (0.264), kendine yetme (-0.053) ve başarma üretkenlik (-0.170) etki yaptığ1 görülmektedir. Standartlaştırılmış regresyon katsayılarına $(\beta)$ göre benlik saygısının dine sığınma tutumu üzerindeki göreceli önem sırası ise; depresif duygulanım $(\beta=.210)$, başarma üretkenlik $(\beta=-.095)$, öz-güven $(\beta=-.074)$, benlik değeri $(\beta=-.035)$ ve kendine güven $(\beta=-.030)$ şeklindedir.

Regresyon katsayılarının anlamlılı̆̆ını sınamak için uygulanan t testi sonuçlarına göre, benlik saygısı beş alt boyutundan sadece depresif duygulanım alt boyutunun dine sığınmanın anlamlı bir yordayıcısı olduğu görülmektedir ( $\mathrm{t}=-2.384, \mathrm{p}=.016)$. Buna karşıllk benlik değeri $(\mathrm{t}=.406, \mathrm{p}>.05)$, öz-güven ( $\mathrm{t}=.905$, $\mathrm{p}>.05)$, kendine yetme $(\mathrm{t}=.425, \mathrm{p}>.05)$ ve başarma üretkenlik $(\mathrm{t}=1.221, \mathrm{p}>.05)$ dine sı̆̆ınma tutumunun anlamlı yordayıcıları olmadığı görülmüştür. Regresyon analizi sonuçlarına göre, benlik saygısının dine sığınma tutumunu yordamasına ilişkin denklem şu şekilde oluşmuştur:

Dine sığınma $=3.719+($ Benlik değeri $x$-.057) $+($ Öz-güven x -.171) + (Depresif duygulanım x .264) + (Kendine yetme x -.053) + (Başarma ve üretkenlik x -.170).

Tablo 2.Benlik Saygısı ile Stresle Başą̧ı-mada Dış Yardım Arama Arasındaki İliskiviye Ait Bulgular

\begin{tabular}{|c|c|c|c|c|c|c|c|c|}
\hline & $B$ & Standart Hata & Beta & $t$ & $p$ & $t$ & Partial t & Patt 1 \\
\hline (Sabit) & 3.079 & .216 & & 14.286 & .000 & & & \\
\hline Benlik Değeri & .129 & .084 & .133 & 1.546 & .123 & -.034 & .089 & .089 \\
\hline Öz Güven & -.077 & .113 & -.056 & -.677 & .499 & -.095 & -.039 & -.039 \\
\hline Depresif Duygulanım & -.134 & .071 & -.150 & -2.888 & .034 & -.125 & -.109 & -.108 \\
\hline Kendine Yetme & -.033 & .074 & -.032 & -.449 & .654 & -.068 & -.026 & -.026 \\
\hline Başarma ve Üretkenlik & -.036 & .084 & -.034 & -.432 & .666 & -.084 & -.025 & -.025 \\
\hline \multicolumn{2}{|c|}{ Bağımlı Değisken: Dıs Yardım Arama } & & \multicolumn{2}{|c|}{$\mathrm{F}=4.495 . \mathrm{p}<.05$} & $\mathrm{R}=.157$ & \multicolumn{3}{|c|}{$\mathrm{R}^{2}=.025$} \\
\hline
\end{tabular}

Tablo 2 incelendiğinde, stresle başaçıkma tutumlarından dış yardım arama ile benlik saygısının tüm alt boyutlarında benlik değeri ( $\mathrm{r}=-.034)$, öz-güven $(\mathrm{r}=-.095)$, depresif duygulanım $(\mathrm{r}=-.125)$, kendine yetme $(\mathrm{r}=-.068)$ ve başarma üretkenlik ( $\mathrm{r}=-.084)$ alt boyutları arasında negatif bir ilişkinin olduğu görülmektedir. Bu durum benlik değeri, öz-güven, depresif duygulanım, kendine yetme ve başarma üretkenlik arttıkça dış yardım arama puanlarının düştüğ̈ünü ortaya koymaktadır. 
Benlik saygısının alt boyutları ile stresle başaçıkmada dış yardım arama tutumu arasında kurulan model istatistiksel bakımdan anlamlı bulunmuştur $(\mathrm{F}=4.495, \mathrm{p}<.05)$. Bu durum genel olarak benlik saygısının dış yardım arama tutumunu anlamlı düzeyde açıkladığını göstermektedir. Benlik saygısı beş alt boyutu ile birlikte (benlik değeri, öz-güven, depresif duygulanım, kendine yetme, başarma ve üretkenlik) dış yardım arama tutumuna ilişkin varyansın $\%$ 2,5’ini açıklamaktadır $\left(\mathrm{R}=.157, \mathrm{R}^{2}=.025\right)$. Bu durum dış yardım arama tutumunun \% 2,5'inin benlik saygısı tarafından belirlendiğini göstermektedir.

Standartlaştırllmamış Beta katsayılanı incelendiğinde dış yardım arama tutumuna ait her bir puan üzerinde benlik değeri (.129), öz-güven (-.077), depresif duygulanım (-.134), kendine yetme (-.033) ve başarma üretkenlik (-.036) etki yaptığı görülmektedir. Standartlaştırılmış regresyon katsayılarına ( $\beta$ ) göre benlik saygısının dış yardım arama tutumu üzerindeki göreceli önem sırası ise; benlik değeri $(\beta=.133)$, depresif duygulanım $(\beta=-.150)$, öz-güven $(\beta=-.056)$, başarma ve üretkenlik $(\beta=-.034)$ ve kendine yetme $(\beta=-.032)$ şeklindedir.

Regresyon katsayılarının anlamlılı̆ı̆ı sınamak için uygulanan t testi sonuçlarına göre, beş benlik saygisı alt boyutundan sadece depresif duygulanım alt boyutunun dıss yardım aramanın anlamlı bir yordayıcısı olduğu görülmektedir ( $\mathrm{t}=-2.888 ; \mathrm{p}=.034)$. Buna karşıllk benlik değeri ( $\mathrm{t}=1.546 ; \mathrm{p}>.05)$, özgüven ( $\mathrm{t}=-.677 ; \mathrm{p}>.05)$, kendine yetme $(\mathrm{t}=-.449 ; \mathrm{p}>.05)$, başarma ve üretkenlik $(\mathrm{t}=-.432 ; \mathrm{p}>.05)$ dış yardım arama tutumunun anlamlı yordayıcıları olmadığı görülmüştür. Regresyon analizi sonuçlarına göre, benlik saygısının dış yardım arama tutumunu yordamasına ilişkin denklem şu şekilde oluşmuştur:

Dış yardım arama $=3.079+($ Benlik değeri x .129) $+($ Öz güven $\mathrm{x}-.077)+($ Depresif duygulanım $\mathrm{x}-$ $.134)+($ Kendine yetme $\mathrm{x}-.033)+$ (Başarma ve üretkenlik $\mathrm{x}-.036)$.

Tablo 3.Benlike Saygısı ile Stresle Basacıımada Aktif Planlama Arasindaki Illiskiye Ait Bulgular

\begin{tabular}{lcccccccc}
\hline & $\boldsymbol{B}$ & Std. Hata & Beta & $\boldsymbol{t}$ & $\boldsymbol{p}$ & $\boldsymbol{r}$ & Partial $\boldsymbol{r}$ & Part $\boldsymbol{r}$ \\
\hline (Sabit) & 4.319 & .266 & & 16.211 & .000 & & & \\
Benlik Değeri & .034 & .103 & .028 & .332 & .740 & .197 & .019 & .018 \\
Öz Güven & .094 & .140 & .053 & .673 & .502 & .179 & .039 & .037 \\
Depresif Duygulanım & -.181 & .088 & -.158 & -2.059 & .040 & -.240 & -.119 & -.114 \\
Kendine Yetme & .174 & .092 & .130 & 1.984 & .043 & .234 & .109 & .105 \\
Başarma ve Üretkenlik & .220 & .103 & -.160 & -2.130 & .034 & -.260 & .123 & .118 \\
\hline Bağı̆mlı Değişken: Aktif Planlama & $\mathrm{F}=6.229 ; \mathrm{p}<.05$ & & $\mathrm{R}=.308$ & & $\mathrm{R}^{2}=.095$ & & \\
\hline
\end{tabular}

Tablo 3 incelendiğinde, stresle başaçıkma tutumlarından benlik saygısının depresif duygulanım $(\mathrm{r}=$ .240) ve başarma ve üretkenlik ( $\mathrm{r}=-.260)$ alt boyutları arasında negatif bir ilişkinin olduğu görülürken, benlik değeri ( $r=.197)$, öz-güven ( $r=.179)$ ve kendine yetme $(r=.234)$ alt boyutları arasında pozitif ilişkinin olduğu saptanmıştır. Bu durum depresif duygulanım ve başarma ve üretkenlik arttıkça aktif planlama puanlarının düştüğünü, buna karşılık benlik değeri, öz-güven ve kendine yetme puanları yükseldikçe aktif planlamanın da yükseldiğini ortaya koymaktadır.

Benlik saygisının alt boyutları ile stresle başaçıkmada aktif planlama arasında kurulan model istatistiksel bakımdan anlamlı bulunmuştur $(\mathrm{F}=6.229, \mathrm{p}<.05)$. Bu durum genel olarak benlik saygisının aktif planlama tutumunu anlamlı düzeyde açıkladığını göstermektedir. Benlik saygısı beş alt boyutu ile birlikte (benlik değeri, öz-güven, depresif duygulanım, kendine yetme, başarma ve üretkenlik) aktif planlama tutumuna ilişkin varyansın\% 9,5'ini açılamaktadır $\left(\mathrm{R}=.308, \mathrm{R}^{2}=.095\right)$. Bu durum aktif planlama tutumunun \% 9,5'inin benlik saygısı tarafından belirlendiğini göstermektedir.

Standartlaştırlmamış Beta katsayıları incelendiğinde aktif planlamaya ait her bir puan üzerinde benlik değeri (.034), öz-güven (.094), depresif duygulanım (-.181), kendine yetme (.174) ve başarma ve üretkenlik (.220) etki yaptığı görülmektedir. Standartlaştırılmış regresyon katsayılarına ( $\beta$ ) göre benlik saygısının aktif planlama tutumu üzerindeki göreceli önem sırası ise; kendine yetme $(\beta=.130)$, öz güven $(\beta=.053)$, benlik değeri $(\beta=.028)$, başarma ve üretkenlik $(\beta=-.160)$ ve depresif duygulanım $(\beta=-.158)$ şeklindedir.

Regresyon katsayılarının anlamlılı̆̆ını sınamak için uygulanan $\mathrm{t}$ testi sonuçlarına göre, benlik saygisı alt boyutlarından depresif duygulanım $(\mathrm{t}=-2.059 ; \mathrm{p}=.040)$, kendine yetme $(\mathrm{t}=1.984 ; \mathrm{p}=.043)$ ve başarma ve üretkenlik ( $\mathrm{t}=-2.130 ; \mathrm{p}=.034)$ alt boyutlarının aktif planlamanın anlamlı yordayıcısı olduğu görülmektedir. Buna karşlık benlik değeri $(\mathrm{t}=.332 ; \mathrm{p}>.05)$ ve öz-güven $(\mathrm{t}=.673 ; \mathrm{p}>.05)$ alt boyutları aktif planlama alt boyutunu anlamlı düzeyde yordamadığı görülmektedir. Regresyon analizi sonuçlarına göre, benlik saygısının aktif planlama tutumunu yordamasına ilişkin denklem şu şekilde oluşmuştur: 
Aktif planlama $=4.319+($ Benlik değeri $\times$.034 $)+($ Öz-güven $x$.094 $)+($ Depresif duygulanım $x-.181)$

$+($ Kendine yetme x .174) + (Başarma ve üretkenlik x .220).

Tablo 4.Benlik Saygısı ile Stresle Başaçkmada Kacma-Soyutlanma (Duygusal Eylemsel) Arasındaki İliskije Ait Bulgular

\begin{tabular}{|c|c|c|c|c|c|c|c|c|}
\hline & $B$ & Std. Hata & Beta & $t$ & $p$ & $r$ & Partial & Part \\
\hline (Sabit) & 2.850 & .233 & & 12.214 & .000 & & & \\
\hline Benlik Değeri & -.101 & .091 & -.096 & 3.119 & .001 & -.069 & -.065 & -.064 \\
\hline Öz Güven & -.096 & .123 & -.064 & .785 & .433 & -.061 & -.046 & -.045 \\
\hline Depresif Duygulanım & .017 & .077 & .018 & .223 & .823 & .043 & .013 & .013 \\
\hline Kendine Yetme & -.195 & .081 & -.172 & 2.416 & .016 & -.070 & -.139 & -.138 \\
\hline Başarma ve Üretkenlik & -.064 & .091 & -.055 & .701 & .484 & -.049 & -.041 & -.040 \\
\hline \multicolumn{3}{|c|}{ Bağımlı Değişken: Kaçma-Soyutlama } & 3.497 .1 & & $\mathrm{R}=.267$ & & $\mathrm{R}^{2}=.071$ & \\
\hline
\end{tabular}

Tablo 4 incelendiğinde stresle başaçıkma tutumlarından kaçma soyutlanma (duygusal eylemsel) ile benlik saygısının benlik değeri $(\mathrm{r}=-.069)$, öz-güven $(\mathrm{r}=-.061)$, kendine yetme $(\mathrm{r}=-.070)$ ve başarma ve üretkenlik ( $\mathrm{r}=-.049)$ alt boyutları arasında negatif bir ilişkinin olduğu görülmektedir. Buna karşlık benlik saygısının depresif duygulanım boyutu ile stresle başaçıkmada kaçma-soyutlanma arasında ise pozitif ilişki saptanmıştır ( $\mathrm{r}=.043)$. Bu durum benlik değeri, öz-güven, kendine yetme ve başarma ve üretkenlik arttıkça kaçma-soyutlanma puanlarının düştüğünü, buna karşılık depresif duygulanım puanları yükseldikçe kaçma soyutlanma puanlarının da yükseldiğini ortaya koymaktadır.

Benlik saygısının alt boyutları ile stresle başaçıkmada kaçma-soyutlama arasında kurulan model istatistiksel bakımdan anlamlı bulunmuştur $(\mathrm{F}=3.497, \mathrm{p}<.05)$. Bu durum genel olarak benlik saygısının kaçma-soyutlanma tutumunu anlamlı düzeyde açıkladığını göstermektedir. Benlik saygısı alt boyutları ile birlikte kaçma-soyutlanma tutumuna ilişkin varyansın\% 7,1'ini açıklamaktadır ( $\left.\mathrm{R}=.267, \mathrm{R}^{2}=.071\right)$. Bu durum kaçma-soyutlanma tutumunun \% 7,1’inin benlik saygısı tarafından belirlendiğini göstermektedir.

Standartlaştırlmamış Beta katsayıları incelendiğinde kaçma soyutlanma tutumuna ait her bir puan üzerinde benlik değeri (-.101), öz-güven (-.096), depresif duygulanım (.017), kendine yetme (-.195) ve başarma ve üretkenlik (-.064) etki yaptığı görülmektedir. Standartlaştırılmış regresyon katsayılarına ( $\beta$ ) göre benlik saygısının kaçma-soyutlama (duygusal eylemsel) tutumu üzerindeki göreceli önem sırası ise; depresif duygulanım $(\beta=.018)$, kendine yetme ( $\beta=-.172)$, benlik değeri $(\beta=-.096)$, öz-güven $(\beta=-.064)$ ve başarma ve üretkenlik $(\beta=-.055)$ şeklindedir. Regresyon katsayılarının anlamlılığını sınamak için uygulanan $t$ testi sonuçlarına göre, beş benlik saygısı alt boyutlarından benlik değeri $(\mathrm{t}=3.119 ; \mathrm{p}=.001)$ ve kendine yetme $(\mathrm{t}=2.416 ; \mathrm{p}=.016)$ kaçma-soyutlamanın anlamlı yordayıcısı olduğu görülmektedir. Buna karşıllk öz-güven $(\mathrm{t}=.785 ; \mathrm{p}>.05)$, depresif duygulanım $(\mathrm{t}=.223 ; \mathrm{p}>.05)$ ve başarma ve üretkenlik $(\mathrm{t}=.701 ; \mathrm{p}>.05)$ alt boyutları kaçma-soyutlamanın anlamlı yordamadığı görülmektedir. Regresyon analizi sonuçlarına göre, benlik saygısının kaçma-soyutlanma tutumunu yordamasına ilişkin denklem şu şekilde oluşmuştur:

Kaçma-soyutlama $=2.850+($ Benlik değeri x -.101) $+($ Öz-güven x -.096) $+($ Depresif duygulanım $\mathrm{x}$ $.017)+($ Kendine yetme $\mathrm{x} .-195)+($ Başarma ve üretkenlik x -.064)

Tablo 5.Benlik Saygısı ile Stresle Başaçımada Kacma-soyutlama (biyokimyasal) Arasindaki Iliskkije Ait Bulgular

\begin{tabular}{lcccccccc}
\hline \multicolumn{1}{c}{ Model } & $\boldsymbol{B}$ & Std. Error & Beta & $\boldsymbol{t}$ & $\boldsymbol{p}$ & $\boldsymbol{r}$ & Partial & Part \\
\hline (Sabit) & 1.170 & .495 & & 2.366 & .019 & & & \\
Benlik Değeri & -.070 & .192 & -.031 & -.362 & .717 & -.084 & -.021 & -.021 \\
Öz Güven & -.133 & .260 & .042 & .509 & .611 & -.106 & -.030 & -.029 \\
Depresif Duygulanım & .479 & .163 & .087 & 3.096 & .001 & .318 & .263 & .142 \\
Kendine Yetme & -.114 & .171 & .048 & .667 & .505 & -.095 & -.039 & -.038 \\
Başarma ve Üretkenlik & -.039 & .192 & .016 & .204 & .839 & -.092 & -.012 & -.012 \\
\hline Bağımlı Değişken: Kaçma-soyutlanma(biyokimyasal) & $\mathrm{F}=3.093 . \mathrm{p}<.05$ & $\mathrm{R}=.304$ & & $\mathrm{R}^{2}=.092$ & \\
\hline
\end{tabular}

Tablo 5 incelendiğinde stresle başa çıkma tutumlarından kaçma soyutlama (biyokimyasal) ile benlik saygisının benlik değeri ( $\mathrm{r}=-.084)$, öz-güven $(\mathrm{r}=-.106)$, kendine yetme $(\mathrm{r}=-.095)$ ve başarma ve üretkenlik $(\mathrm{r}=-.092)$ alt boyutları arasında negatif bir ilişkinin olduğu görülmektedir. Buna karşıllk benlik saygısının depresif duygulanım ( $\mathrm{r}=.318)$ boyutu ile stresle başa çıkmada kaçma-soyutlama arasında ise pozitif ilişki 
saptanmıştır. Bu durum benlik değeri, öz-güven, kendine yetme ve başarma ve üretkenlik arttıkça kaçma soyutlama (biyokimyasal) puanlarının düştüğünü, buna karşılık depresif duygulanım puanları yükseldikçe kaçma soyutlama puanlarının da yükseldiğini ortaya koymaktadır.

Benlik saygısının alt boyutları ile stresle başaçıkmada kaçma soyutlama (Biyokimyasal) arasında kurulan model istatistiksel bakımdan anlamlı bulunmuştur $(\mathrm{F}=3.093, \mathrm{p}<.05)$. Bu durum genel olarak benlik saygısının kaçma soyutlama tutumunu anlamlı düzeyde açıladığını göstermektedir. Benlik saygısı alt boyutları ile birlikte (benlik değeri, öz güven, depresif duygulanım, kendine yetme, başarma ve üretkenlik) kaçma soyutlama tutumuna ilişkin varyansın\% 9,2'sini açıklamaktadır ( $\left.\mathrm{R}=.304, \mathrm{R}^{2}=.092\right)$. Bu durum kaçma-soyutlanma (biyokimyasal) tutumunun \% 9,2'sinin benlik saygısı tarafindan belirlendiğini göstermektedir.

Standartlaştırılmamış Beta katsayılanı incelendiğinde kaçma soyutlama (biyokimyasal) tutumuna ait her bir puan üzerinde benlik değeri (-.070), öz-güven (-.133), depresif duygulanım (.479), kendine yetme (-.114) ve başarma ve üretkenlik (-.039) etki yaptığı görülmektedir. Standartlaştırlmış regresyon katsayılarına ( $\beta$ ) göre benlik saygisının kaçma soyutlama tutumu üzerindeki göreceli önem sırası ise; depresif duygulanım ( $\beta=.087)$, kendine yetme ( $\beta=.048)$, öz-güven $(\beta=.042)$, başarma ve üretkenlik $(\beta=.016)$ ve benlik değeri $(\beta=-.031)$ şeklindedir.

Regresyon katsayılarının anlamlılı̆̆ını sınamak için uygulanan $\mathrm{t}$ testi sonuçlarına göre, benlik saygısı alt boyutlarından depresif duygulanımın ( $\mathrm{t}=3.096 ; \mathrm{p}=.001)$ kaçma soyutlamanın anlamlı yordayıcısı olduğu görülmektedir. Buna karşıllk benlik değeri ( $\mathrm{t}=-.362 ; \mathrm{p}>.05)$, öz-güven $(\mathrm{t}=.509 ; \mathrm{p}>.05)$, kendine yetme $(\mathrm{t}=.667 ; \mathrm{p}>.05)$ ve başarma ve üretkenlik $(\mathrm{t}=.204 ; \mathrm{p}>.05)$ alt boyutları kaçma soyutlamanın anlamlı yordayıcısı olmadığı görülmüştür.

Regresyon analizi sonuçlarına göre, benlik saygısının kaçma-soyutlanma (biyokimyasal) tutumunu yordamasına ilişkin denklem şu şekilde oluşmuştur:

Kaçma-soyutlanma (biyokimyasal) $=1.170+($ Benlik değeri $\mathrm{x}-.070)+($ Öz-güven $\mathrm{x}-.133)+$

(Depresif duygulanım x .479) + (Kendine yetme x -.114) + (Başarma ve üretkenlik x -.039).

Tablo 6. Benlik. Saygısı ile Stresle Başaçıkmada Kabul-Bilissel Yeniden Yapılandirma Arasmdaki Ilisskiye Ait Bulgular

\begin{tabular}{lcccccccc}
\hline & $\boldsymbol{B}$ & Std. Hata & Beta & $\boldsymbol{t}$ & $\boldsymbol{p}$ & $\boldsymbol{r}$ & Partial $\boldsymbol{r}$ & Part $\boldsymbol{r}$ \\
\hline (Sabit) & 4.233 & .281 & & 15.067 & .000 & & & \\
Benlik Değeri & .061 & .109 & .047 & .559 & .576 & .199 & .032 & .031 \\
Öz Güven & .109 & .148 & .059 & .740 & .460 & .155 & .043 & .041 \\
Depresif Duygulanım & -.119 & .093 & -.300 & -3.287 & .019 & -.402 & -.074 & -.072 \\
Kendine Yetme & .110 & .097 & .079 & 1.138 & .256 & .190 & .066 & .064 \\
Başarma ve Üretkenlik & .214 & .109 & .150 & 1.966 & .049 & .232 & .113 & .110 \\
\hline Bağımsız Değişken: Kabul-Bilişsel Yeniden Yapilandırma & $\mathrm{F}=4.487 . \mathrm{p}<.05$ & $\mathrm{R}=.365$ & & $\mathrm{R}^{2}=.133$ \\
\hline
\end{tabular}

Tablo 6 incelendiğinde, stresle başaçıkma tutumlarından kabul-bilişsel yeniden yapılandırma ile benlik saygisının sadece depresif duygulanım $(r=-.402)$ alt boyutu arasında negatif bir ilişkinin olduğu görülmektedir. Buna karşılık benlik saygısının benlik değeri ( $\mathrm{r}=.199)$, öz-güven ( $\mathrm{r}=.155)$, kendine yetme $(\mathrm{r}=.190)$ ve başarma ve üretkenlik $(\mathrm{r}=.232)$ boyutları ile stresle başaçıkmada kabul-bilişsel yeniden yapılandırma arasında pozitif ilişki saptanmıştır. Bu durum depresif duygulanım arttıkça kabul-bilişsel yeniden yapılandırma puanlarının düştügünü, buna karşılık benlik değeri, öz güven, kendine yetme ve başarma ve üretkenlik puanları yükseldikçe kabul-bilişsel yeniden yapılandırma puanlarının da yükseldiğini ortaya koymaktadır.

Benlik saygısının alt boyutları ile stresle başa çıkmada kabul-bilişsel yeniden yapılandırma arasında kurulan model istatistiksel bakımdan anlamlı bulunmuştur $(\mathrm{F}=4.487, \mathrm{p}<.05)$. Bu durum genel olarak benlik saygisının kabul-bilişsel yeniden yapılandırma tutumunu anlamlı düzeyde açıkladığını göstermektedir. Benlik sayg1sı alt boyutları ile birlikte (benlik değeri, öz-güven, depresif duygulanım, kendine yetme, başarma ve üretkenlik) kabul-bilişsel yeniden yapılandırma tutumuna ilişkin varyansın $\%$ 13,3'ünü açıklamaktadır $\left(\mathrm{R}=.365, \mathrm{R}^{2}=.133\right)$. Bu durum kabul-bilişsel yeniden yapılandırma tutumunun \% 13,3’ünün benlik saygisı tarafindan belirlendiğini göstermektedir.

Standartlaştırılmamış Beta katsayıları incelendiğinde kabul-bilişsel yeniden yapılandırma tutumuna ait her bir puan üzerinde benlik değeri (.061), öz-güven (.109), depresif duygulanım (-.119), kendine yetme 
(.110) ve başarma ve üretkenlik (.214) etki yaptığı görülmektedir. Standartlaştırılmış regresyon katsayılarına ( $\beta$ ) göre benlik saygısının kabul-bilişsel yeniden yapılandırma tutumu üzerindeki göreceli önem sırası ise; başarma ve üretkenlik $(\beta=.150)$, kendine yetme $(\beta=.079)$, öz güven $(\beta=.059)$, benlik değeri $(\beta=.047)$ ve depresif duygulanım $(\beta=-.119)$ şeklindedir.

Regresyon katsayılarının anlamlılı̆ını sınamak için uygulanan t testi sonuçlarına göre, beş benlik saygıs1 alt boyutlarından depresif duygulanım ( $\mathrm{t}=-3.287 ; \mathrm{p}=.019)$ ve başarma ve üretkenliğin ( $\mathrm{t}=1.966$; $\mathrm{p}=.049)$ kabul-bilişsel yeniden yapılandırmanın anlamlı yordayıcısı olduğu görülmektedir. Buna karşılık benlik değeri ( $\mathrm{t}=.559 ; \mathrm{p}>.05)$, öz-güven $(\mathrm{t}=.740 ; \mathrm{p}>.05)$ ve kendine yetme $(\mathrm{t}=1.138 ; \mathrm{p}>.05)$ alt boyutlar1 kabul-bilişsel yeniden yapılandırmanın anlamlı yordayıcıları olmadığı görülmüştür. Regresyon analizi sonuçlarına göre, benlik saygısının kabul-bilişsel yeniden yapılandırma tutumunu yordamasına ilişkin denklem şu şekilde oluşmuş̧tur:

Kabul-bilişsel yeniden yapılandırma $=4.233+($ Benlik değeri $\times$.061 $)+($ Öz-güven $\times$.109 $)+$ (Depresif duygulanım x -.119) + (Kendine yetme x .110) + (Başarma ve üretkenlik x .214).

Benlik saygısı ile stresle başaçıkma tutumları arasındaki ilişkisel değerler Şekil 1'de özetlenmiştir.

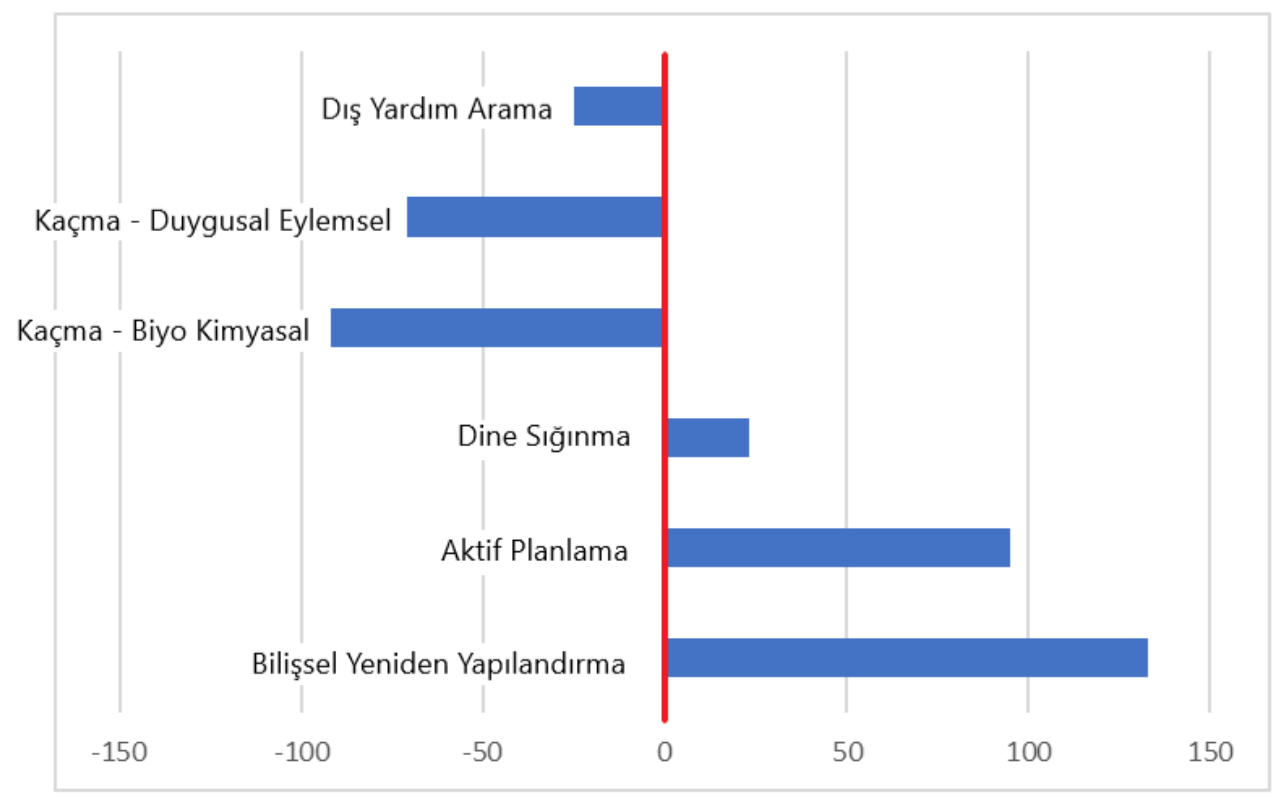

Şekil 1. Benlik Saygısı İle Stresle Başaçıma Tutumlar Arasindaki Iliskisisel Değerler

\section{Tartışma, Sonuç ve Öneriler}

$\mathrm{Bu}$ araştırmada, üniversite öğrencilerinin benlik saygıları ile stresle başaçıkma tutumları arasındaki ilişki ve benlik saygısının stresle başaçıkma tutumlarını yordama gücü incelenmiştir. Çalışmanın sonuçları üniversite öğrencilerinin benlik saygısının stresle başaçıkmada bilişsel yeniden yapılandırma, aktif planlama ve dine sığınma ile pozitif yönlü bir ilişki içinde olduğunu göstermiştir. Buna karşılık, kaçma biyo-kimyasal, kaçınma duygusal-eylemsel ve dış yardım arama, benlik saygısı ile negatif yönlü bir ilişki göstermektedir. Araştırmada benlik saygısının benlik değeri, öz-güven, kendine yetme, başarma ve üretkenlik boyutlarının istatistiksel olarak anlamlı ve en güçlü yordayıcısının stresle başaçıkmada kabul-bilişsel yeniden yapılandırma olduğu saptanmıştır. Ölçekte kabul-bilişsel yeniden yapılandırma, problemin kabul edilip kendince bilişsel olarak yeni çözüm yollarının aranması olarak açılanmakta ve başaçıkmada kişisel olarak durumun değiş̧tirilmesine yönelik bir işlemden daha çok kişinin bakış açısını vurgulamaktadır (Özbay ve Şahin, 1997). Literatür incelendiğinde, araştırmadan elde edilen bu bulguyu destekleyen benzer çalışmalar (Hamarta vd.,2009; Tagay vd., 2009; Avşaroğlu, 2007; Parmaksız ve Avşaroğlu, 2012) olduğu görülmektedir. Hamarta vd., (2009) benlik saygısı yüksek olan üniversite öğrencilerinin problem odaklı başaçıkma düzeylerinin de yüksek olduğunu belirlemişlerdir (Hamarta vd., 2009, s. 40). Tagay vd. (2018) benlik saygısı ile stresle sağııkı başa çıkma arasında paralel bir ilişkinin olduğunu saptamışlardır (Tagay vd., 2018, s. 173). Benzer şekilde Avşaroğlu'na (2007) göre benlik saygisı ile stresle sağlıklı başaçıkma arasında pozitif düzeyde anlamlı ilişki bulunmaktadır (Avşaroğlu, 2007, s. 125). Diğer bir çalışmada (Parmaksız ve 
Avşaroğlu, 2012, s. 552), Öğretmen adaylarının benlik saygısı, iyimserlik ve stresle başaçıkma arasında anlamlı ilişkilerin olduğunu vurgulamışlardır.

Bilişsel yeniden yapılandırmaya ek olarak üniversite öğrencilerinin benlik saygılarının benlik değeri, özgüven ve kendine yetme alt boyutları ile stresle başaçıkma boyutlarından aktif planlama arasında pozitif yönlü orta düzeyde anlamlı bir ilişki bulunmuştur. Ölçekte aktif planlama aktif olarak bir şeyler yapma, doğrudan işleme başlama, aktif çabaları artırma, eylem planları oluşturma, şu an üzerinde odaklaşma ve problem çözme sistematiği içerisinde olmayı içeren rasyonel adımlar ve yöntemler olarak açıklanmaktadır (Özbay ve Şahin, 1997). Avşaroğlu'na göre üniversite öğrencilerinin benlik sayg1sı alt boyutları, stresle başaçıkma stillerinden aktif planlamayı anlamlı düzeyde açıklamaktadır (Avşaroğlu, 2007, s. 148). Dolayısılla özgüven ve kendine yetme algısının, aktif planlama stili üzerinde olumlu etkisi olduğu görülmektedir. Başka bir açıdan bakıldığında, aktif planlama stili, kendine yetme ve özgüven algısını daha da olumlu yöne çekmesi bağlamında bu durumun karşıllklı ve pozitif yönde ilişki içinde olduğu söylenebilir (Avşaroğlu, 2007, s. 122). Başarılı ve kendine güven duyan bireylerin, depresifler gibi kendilerini zayıf ve çaresiz hissetmek yerine mücadele ederek sorunlarının üstesinden gelme çabası verdikleri söylenebilir (Parmaksız ve Avşaroğlu, 2012, s. 553). Araştırma sonucu, üniversite öğrencilerinin benlik değeri, özgüveni ve kendine yetme düzeyleri arttıkça öğrencilerin aktif planlama tutumlarında da yükselme olmaktadır şeklinde yorumlanabilir.

Diğer bir alt boyut olan ve dine sığınmanın da benlik saygısının alt boyutu olan depresif duygulanımın yordayıcısı olduğu saptanmıştır. Ölçekte bu faktör altında toplanan maddeler daha çok bir ilahi güce sığınmayı, dua etmeyi ve inançlardan güç almayı vurgulamaktadır (Özbay ve Şahin, 1997). Stres anında yaşanan durum ya da olayla baş edebilmek için bireylerin dine yönelmeleri bilinçli bir yönelmedir (Kavas, 2013, s. 148). Benlik saygısının alt boyutlarından bir olan depresif duygulanım ile stresle başaçıkmada dine sığınma arasında pozitif ilişki tespit edilen araştırmalar da bu bulguyu destekler niteliktedir. Öğrencilerin benlik saygısı alt ölçeklerinin, stresle başaçıkma stilleri alt boyutlarından dine yönelmeyi anlamlı düzeyde açıkladığı (Avşaroğlu, 2007, s. 124) vurgulanmaktadır. Battle (1978), Workman ve Beer (1989), Gür (1996) benlik saygısı düzeyleri ile depresyonları arasında anlamlı bir ilişkinin olduğunu belirtmiştir (Akt: Parmaksız, 2011, s. 78). Zor zamanlarda duaya yönelme düzeyi ile stresle başa çıkma arasında olumlu yönde bir ilişki olduğu görülmüştür (Aydın, 2011, s. 136-137). Kavas (2013) dinî tutum puanı ortalamaları ile stresle başaçıkma tutum puanı ortalamaları arasında pozitif yönde çok zayıf bir ilişki saptanmış olsa da bireylerin stresle başa çıkmasında dinî tutumların önemli bir yerinin olduğunnu ileri sürmektedir (Kavas, 2013, s. 165). Üniversite öğrencilerinin benlik saygısının depresif duygulanım boyutu ile stresle başaçıkmada dine sı̆̆ınma arasındaki pozitif ilişki depresif duygulanım düzeyi yüksek olan bireyin dine sığınma tutumlarının da yüksek olduğunu göstermektedir şeklinde yorumlanabilir.

$\mathrm{Bu}$ araştırmada elde edilen bulgular dikkate alındığında benlik saygısı ile stresle başaçıkma tutumları arasında güçlü bir ilişkinin olduğu söylenebilir. Benlik saygını oluşturan boyutların toplamı hesaba alındığında, benlik saygısı yüksek insanların stresle başaçıkma tutumlarında daha başarılı olduğu söylenebilir. Bu bağlamda okullarda benlik saygını artırıcı eğitim öğretim ve öğrenci kişilik hizmetleri çerçevesinde rehberlik ve psikolojik danışma hizmetleri sağlanabilir. Benlik gelişimi özellikle erken dönemlerde daha önemli olduğu için temel eğitimden üniversite yıllarına kadar bireylerin benlik saygını artırıcı öğretmen tutumları, anne-baba tutumları ve stres durumlarıly başaçıkma becerisi kazanmaya dönük sosyal beceri eğitimleri verilebilir.

\section{Kaynakça}

Arıcak, O. T. (1999). Grupla psikolojik damısma yoluyla benlik saygısi ve mesleki benlik saygssmnn gelistirilmesi (Doktora Tezi). Marmara Üniversitesi, Sosyal Bilimler Enstitüsü, İstanbul.

Avşaroğlu, S. (2007). Üniversite ögrencilerinin karar vermede özsayg̨, karar verme ve stresle başagııma stillerinin benlik saygısı ve baそ̌l değğskenler açssndan incelenmesi (Doktora Tezi). Selçuk Üniversitesi, Sosyal Bilimler Enstitüsü, Konya.

Aydın, C. ve Cavuş, S. (2017). Kuşadası konaklama işletmelerinde çalışanların örgütsel stres ve tükenmişlik düzeyleri. Manas Sosyal Arastrumalar Dergisi, 6(5), 79-95.

Aydın, İ. (2016). Issyasammnda stres (4.Baskı). Ankara: Pegem Akademi Yayınları.

Aydın, Ö. (2011). Yaşamı sürdürmede din̂̂ inancun rolï (Doktora Tezi). Ankara Üniversitesi, Sosyal Bilimler Enstitüsü, Ankara.

Baltaş, Z. (2010). Verimli iş hayatmmn sırr: Stres (4. Baski). İstanbul: Remzi Kitabevi.

Baltaş, Z. Ve Baltaş, A. (2000). Stres ve bașą̧ıma yollarr. İstanbul: Remzi Kitabevi.

Bektaş, M. ve Karagöz, Ş. (2017). Stresle başaçıkma tarzlarının yalnızlığa etkisi: meslek yüksekokulu öğrencileri üzerinde bir araştırma. Mehmet Akif Ersoy Üniversitesi Sosyal Bilimler Enstituisü Dergisi,9(21), 342-355. doi: 10.20875/makusobed.316905 
Braham, B. J. (1998). Stres yönetimi. Ateş altında sakin kalabilmek (Çev: V. G. Diker). İstanbul: Hayat Yayınları.

Caspi, A., Roberts, B. W. ve Shiner, R. L. (2005). Personality development: Stability and change. Annual Review of Psychology, 56, 453-584.

Cüceloğlu, D. (1994). İnsan ve davranışı: Psikolojinin temel kavramlar. İstanbul: Remzi Kitabevi.

Çam, O. ve Altınköprü, H. (2013). Üniversite öğrencilerinde müziğin ruhsal duruma ve stresle başaçıkma tarzları üzerine etkisi. Motif Akademi Halkbilimi Dergisi,2, 262-272.

Folkman, S. ve Lazarus, R. S. (1988) Coping as a mediator of emotion. Journal of Personality and Social Psychology, 54(3), 466-475.

Hamarta, E., Arslan, C., Saygın, Y. ve Özyeşil, Z. (2009). Benlik sayg1sı ve akılcı olmayan inançlar bakımından üniversite öğrencilerinin stresle başa çıkma yaklaşımlarının analizi. Değerler Eğitimi Dergisi, 7(18), 25-42.

Hancıoğlu, Y. (2017). Üniversite öğrencilerinin algıladıkları stres düzeyleri ile stresle başaçıkma tarzları arasındaki ilişkinin incelenmesi, Yönetim ve Ekonomi Araştırmalar Dergisi, 15(1), 130-149. doi: http://dx.doi.org/10.11611/yead.270449

Kağıtçıbaş1, Ç. (2012). Benlik, aile ve insan gelişimi, kültürel psikoloji (3.Baskı). İstanbul: Koç Üniversitesi Yayınları.

Karasar, N. (2008). Bilimsel arastırma yöntemi. Ankara: Nobel.

Kavas, E. (2013). Dini tutum-stresle başaçıkma ilişkisi. Dumlupınar Üniversitesi Sosyal Bilimler Dergisi, 37(1), 143-168.

LeSergent, M.Ch.ve Haney, C. (2005). Rural hospital nurse's stressors and coping strategies: A Survey International Journal of Nursing Studies, 42, 315-324.

Madenoğlu, C. (2010). Eğitim örgütü yöneticilerinin örgütsel stres kaynaklar ve stresle başaçıkma tarzlarmm benlik. saygısı düzeyleriyle olan ilişkisi (Doktora Tezi). Anadolu Üniversitesi, Sosyal Bilimler Enstitüsü, Eskişehir.

Mark, G. ve Smith, A. P. (2012). Effects of occupational stress, job characteristics, coping and attributional style on the mental health and job satisfaction of university employees. Journal Anxiety, Stress \& Coping an International Journal, 25(1), 63-78. doi: 10.1080/10615806.2010.548088

McCrae, R. R. ve Costa, P. T. Jr., (2008). The five-factor theory of personality. Handbook of personality: Theory and research. New York: Guilford Press.

Orth, U., Robins, R.W., Meier, L.L. ve Conger, R.D. (2016). Refining the vulnerability model of low self-esteem and depression: Disentangling the effects of genuine self-esteem and narcissism. Journal of Personality and Social Psychology, 110(1), 133-149.

Özbay, Y. ve Şahin, B. (1997). Stresle başaçıkma tutumları envanteri: Geçerlik ve güvenirlik çalışması.IV. Ulusal Psikolojik Danısma ve Rehberlik. Kongresi. Ankara, 1-3 Eylül.

Palermiti. A. L., Servidio, R., Bartolo, M. G. ve Costabile, A. (2017). Cyberbullying and self-esteem: An Italian study. Computers in Human Behavior, 69, 136-141.

Parmaksız, İ. (2011). Ögretmen adaylarmm benlik saygısı düzeylerine göre iyimserlik ve stresle basaģıma tutumlarmm incelenmesi (Yüksek Lisans Tezi). Selçuk Üniversitesi, Eğitim Bilimleri Enstitüsü, Konya.

Parmaksız, İ. ve Avşaroğlu, S. (2012). Öğretmen adaylarının benlik saygısı düzeylerine göre iyimserlik ve stresle başaçıkma stillerinin incelenmesi. İlkögretim Online, 11(2), 543-555.

Ptacek, J. T., Smith, R. E.veZanas, J. (1992) Gender, appraisal and coping: A longitudinal analysis. Journal of Personality, 60(4), 747-770.

Robins, R. W., Tracy, J. L., Trzesniewski, K., Potter, J. ve Gosling, S. D. (2001). Personality correlates of self-esteem. Journal of Research in Personality, 35, 463-482.

Savc1, M. ve Aysan, F. (2014). Üniversite öğrencilerinde alg1lanan stres düzeyi ile stresle başaçıkma stratejileri arasındaki ilişki. Uluslararası Türk Ë̆gitim Bilimleri Dergisi, 3, 44-56.

Soysal, A. (2009). İş yaşamında stres. Cimento İşveren Dergisi, Mayıs 2009, 17-40.

Tagay, Ö., Çalışandemir, F. ve Ünüvar, P. (2018). Genç yetişkinlerin algılanan stres düzeyleri ile akılcı olmayan inançları ve benlik saygiları arasındaki ilisski. International Journal of Education Technology and Scientific Researches, 7, 167-175.

Waldron, J. C., Scarpa, A. ve Kim-Spoon, J. (2018). Religiosity and interpersonal problems explain individual differences in self esteem among young adults with child maltreatment experiences. Child Abuse \& Neglect, 80, 277-284.

Yörükoğlu, A. (1993). Gençlik çă̆ı ruh sağhğ̀ ve rubsal sorunlar(8.Baskı). İstanbul: Özgür Yayınları.

\section{EXTENDED ABSTRACT}

The efforts of human beings to be aware of their own characteristics are becoming more and more important day by day. Significance of developing basic skills and above mentioned efforts within the frameworks of education to keep up with rapid changes and progresses happening in the world are increasing. In this process, opportunities should be provided for the individual to define himself and react deliberately. In this process, the self-structures of the individual, the concept of self and self-esteem effect his perception and interaction with life events. Although self-concept and self-esteem are mostly used interchangeably, they have different meanings. Self-esteem is a state of satisfaction which includes different evaluative phenomena rather than self-concept. Self-esteem is one's state of pleasure, which appears from appreciation of self-concept as a result of self-evaluation. One can criticize himself or find 
himself positive. One does not need to have superior qualities in order to respect himself, because selfesteem is a positive mood that allows to be positive, self-satisfied, to be loved and trusted, but not underestimated or overestimated. Self-esteem is related to how much the individual loves, accepts and respects himself.

Coping with stress is another concept, which is thought to be related to self-esteem in this research. Stress can be interpreted as one's compulsive conditions. Reactions to stress can lead to the development of chronic diseases, especially if they remain over a long period of time. Headaches, hypertension, heart diseases, as well as psychological or mental illnesses can be the examples of these diseases. People may develop emotional problems such as withdrawal, acceptance, resentment or fear, anxiety, and depression as a psychological response to their behavioral patterns and mental characteristics. Therefore, stress coping attitudes are important. It is useful to develop various coping techniques related to stress. The developed strategies can be classified as problem-focused coping and emotion-focused coping attitudes. The aim of the study is to determine the relationship between self-esteem and the attitudes of coping with stress. Another objective is to determine whether the total sub-dimensions of self-esteem significantly predict stress-coping attitudes or not.

The research was conducted in accordance with the relational screening model, a sub-type of the general survey model. The study group consists of students, who studied in different faculties of KyrgyzTurkish Manas University and Osh State University in 2017-2018 academic years. The sample group consists of 303 students, who were selected by random sampling method.

"Self-esteem scale", developed by T. Arıcak (1999) and "Attitude of coping with stress inventory", adapted to Turkish by Ozbay and Sahin (1997) were used for data collection. Data obtained from data collection tools were analyzed through SPSS 16.00 package program and correlation and regression analysis were used for determining the relationship between variables.

According to the results of the study self-esteem was found to be positively correlated with such stress-coping dimensions like acceptance-cognitive restructuring, active planning and religious asylum, while negative correlation was found between self-esteem and stress-coping dimensions like avoidanceisolation (biochemical), avoidance-isolation (emotional-actual) and seeking external aid. Among the three variables that were positively correlated with self-esteem the highest disclosure rate was observed in acceptance-cognitive restructuring and the lowest explanation rate was observed in religious asylum. Among the stress coping that were negatively correlated with self-esteem it was found that the variable with the highest explanatory power was avoidance-isolation (biochemical) and the least-explanatory variable was seeking external aid. According to the research findings, it can be said that there is a significant relationship between self-esteem and the attitudes of coping with stress. Self-esteem total subdimensions have a significant relationship with stress coping sub-dimensions and it can be concluded that stress situations can be easily overcome if self-esteem levels are strengthened.

This research was conducted on students of Kyrgyz-Turkish Manas University, located in Bishkek, and Osh State University, located in Osh. Considering the relationship between university students' selfesteem and their coping with stress attitudes, psychology counseling and guidance services of universities can create psychosocial training groups that will help to strengthen students' self-esteem levels. School systems can provide this as a social skills activity in collaboration with school teachers. On the other hand, cooperation with families can contribute to children's self-esteem establishment. Individual abilities can be determined and their achievements and productivity levels can be increased by conducting different group activities, planned in accordance with interests and capacities. This can help to increase their self confidence levels. Group work can be done to improve students' coping skills. Since the perception, interpretation and response of stress situations has cognitive and behavioral dimensions, the cognitive level schemas of young people can be rearranged. Treatment-oriented therapy work on stress situations and their coping can be done through concept analysis and discussions made at home as homework.

According to the findings of the study, another suggestion that can be considered important is that preventive psychological counseling and guidance services that increase self-esteem can be developed with different studies in terms of family education. For this purpose, new field studies and researches can be carried out. 